\title{
INVENTARISASI PATOGEN DI PERTANAMAN NANAS (Ananas comosus L.) VARIETAS QUEEN DI DESA ASTOMULYO, KECAMATAN PUNGGUR KABUPATEN LAMPUNG TENGAH
}

\author{
Maya Gustina, Suskandini Ratih, Muhammad Nurdin \& Radix Suharjo \\ Jurusan Agroteknologi, Fakultas Pertanian Universitas Lampung \\ Jl. Prof. Soemantri Brodjonegoro, No.1 Bandar Lampung 35145 \\ Email: Mayagustina21@gmail.com
}

\begin{abstract}
ABSTRAK
Nanas merupakan salah satu komoditas sumber devisa negara Indonesia dari sektor pertanian. Produksi nanas di Indonesia mengalami peningkatan setiap tahun, namun peningkatan tersebut akan mengalami gangguan dengan adanya serangan patogen. Patogen yang menyerang harus dideteksi lebih dini agar mengetahui cara pengendaliannya. Penelitian ini bertujuan untuk menginventarisasi patogen dan menghitung intensitas penyakit pada berbagai umur nanas varietas Queen di areal perkebunan nanas rakyat di Punggur, Lampung tengah. Penelitian dilakukan di Desa Astomulyo, Punggur, Lampung Tengah dan Laboratorium Penyakit Tanaman, Jurusan Agroteknologi, Fakultas Pertanian, Universitas Lampung, yang berlangsung dari bulan Agustus - Oktober 2015. Penelitian ini diawali dengan pengamatan lahan dan pengambil sampel untuk diidentifikasi sampai tingkat genus di laboratorium serta menghitung intensitas penyakit (metode Townsend dan Heuberger). Hasil penelitian berupa beberapa jamur yang ditemukan pada tanaman yang bergejala. Jamur - jamur tersebut adalah Curvularia sp., Thielaviopsis sp., Fusarium sp. Selain itu ditemukan gejala yang diduga akibat serangan virus PMWaV pada nanas. Selain pertanaman, Isolasi dari tanah ditemukan jamur Penicillium sp., dan Trichoderma sp. Jamur Culvularia sp. menyerang tanaman nanas di umur 5-7 bulan setelah tanam (bst), 8-11 bst, dan 12 bst dengan tingkat keparahan penyakit berturut - turut sebesar 8,4\%, 8,8\%, dan 7,6\%. Jamur Thielaviopsis sp. menyerang tanaman nanas berumur $5-7$ bst, $8-11$ bst dan 12 bst dengan tingkat keparahan penyakit sebesar 7,2\%, 15\% dan 9,3\%. Jamur Fusarium sp. tidak menyerang nanas berumur $5-7$ bst, tetapi menyerang tanaman nanas berumur $8-11$ bst dan 12 bst dengan tingkat keparahan penyakit sebesar 5\% dan $9 \%$.
\end{abstract}

Kata kunci: Curvularia sp., Fusarium sp., Nanas, Patogen, Thielaviopsis sp.

\section{PENDAHULUAN}

Nanas (Ananas comosus L.) merupakan salah satu buah komoditas perdagangan Indonesia. Permintaan buah nanas dari tahun ke tahun mengalami peningkatan, baik dipasarkan dalam negeri maupun luar negeri. Permintaan dalam negeri (domestik) semakin meningkat dikarenakan pertumbuhan jumlah penduduk dan sadarnya nilai vitamin pada buah. Permintaan luar negeri meningkat dapat dilihat dari nilai ekspor nanas Indonesia pada tahun 2014 mencapai US\$ 193,35 juta (PUSDATIN, 2015). Negara tujuan utama ekspor nanas Indonesia adalah Amerika Serikat sebesar US\$ 56,32 juta lalu diikuti dengan beberapa negara lainnya.

Penyakit pada tanaman nanas merupakan salah satu faktor yang bisa mempengaruhi produktivitas nanas. Penyakit nanas bisa dikendalikan secara cepat apabila mengetahui gejala penyakit. Gejala penyakit tanaman nanas merupakan indikasi bahwa tanaman terserang patogen.
Serangan patogen Pineapple mealybug wiltassociated virus (PMWaV) menyebabkan nanas akan mengalami penyakit layu nanas. Menurut hasil survei (Reno, 2006 dalam Lisnawita et al., 2011 ) penyakit layu nanas telah tersebar di hampir seluruh sentra produksi nanas di Indonesia seperti Subang, Blitar dan Sumatera Utara. Bobot produksi nanas yang terserang penyakit layu lebih rendah $35 \%$ dari pada tanaman yang tidak terinfeksi PMWaV (Sether and Hu, 2002). Ciriciri tanaman yang terserang menunjukan gejala layu yang parah bahkan dapat mengalami kematian. Apabila tanaman yang terserang masih dapat bertahan, buah yang dihasilkan berukuran kecil serta cepat masak sehingga tidak bernilai ekonomis.

Serangan patogen juga menyebabkan nanas terkena penyakit busuk buah. Penyakit busuk buah disebabkan oleh beberapa patogen diantaranya jamur Ceratocystis paradoxa dan Fusarium moniliforme. Serangan kedua patogen ini menimbulkan gejala layu pada batang, sedangkan pada buah akan merubah 
warna menjadi kecoklatan serta membuat cekungan di tempat infeksi.

Patogen lain yang menyerang nanas yaitu jamur Curvularia lunata yang menyerang bagian daun nanas. Jamur ini akan menyebabkan daun mempunyai bercak. Bercak ini terjadi dimulai adanya titik berwarna kecoklatan pada daun, titik ini dikelilingi oleh selaput hitam transparan, selaput hitam tersebut akan berubah menjadi kuning muda. Hasil penelitian Susanto dan Prastyo (2013), menunjukkan bahwa penyakit bercak disebabkan oleh jamur Curvularia, dapat juga ditemukan pada rumput teki (Cyperus rotundus) dan alang-alang (Imperata cylindrica).

Oleh karena itu, untuk mengetahui serangan patogen yang menyerang areal pertanaman nanas perlu dilakukan penelitian deteksi dan identifikasi patogen. Penelitian ini bertujuan untuk menginventaris patogen yang terdapat pada tanaman nanas varietas Queen serta mengetahui keparahan penyakit nanas pada tingkat umur tanaman nanas varietas Queen di Punggur Lampung Tengah.

\section{BAHAN DAN METODE}

Penelitian dilakukan di Desa Astomulyo Kecamatan Punggur Lampung Tengah, dan deteksi mikroskopis dilaksanakan di Laboratorium Penyakit Tanaman, Jurusan Agroteknologi, Fakultas Pertanian, Universitas Lampung, dari bulan Agustus sampai Oktober 2015. Bahan - bahan yang digunakan dalam penelitian ini adalah tanah yang berasal dari Desa Astomulyo Kecamatan Punggur Lampung Tengah, alkohol $70 \%$, media PSA (potato sukrosa agar), rose bengal, asam laktat dan aquades. Alat - alat yang digunakan adalah, gelas ukur, cawan petri, mikroskop, buku identifikasi Barnett dan Hunter (1972), autoklaf, bunsen, tabung reaksi, laminar air flow, mikro pipet, kertas tisue, dan plastik.

\section{a. Penentuan Petak Sampel Tanaman}

Petak sampel tanaman ditentukan dengan memilih 9 petani dari 210 jumlah petani yang berada di desa Astomulyo, sehingga terdapat 9 petak kebun pengamatan secara acak terpilih berdasarkan umur tanaman. Pada setiap kebun pengamatan diambil 25 tanaman contoh secara diagonal (Gambar 1).

\section{b. Pengamatan Gejala penyakit}

Gejala penyakit diamati dengan cara melihat pertumbuhan yang abnormal pada tanaman nanas yang terlihat di lapang. Gejala penyakit yang diamati yaitu: penyakit bercak daun, busuk pangkal batang, dan busuk buah. Suatu patogen sering menimbulkan gejala penyakit yang bersifat khas.

c. Perhitungan Keterjadian Penyakit

Keterjadian penyakit diamati dengan melihat tanaman sampel yang terkena serangan patogen di lapang, kemudian tanaman sampel dihitung dengan rumus sebagai berikut:

Keterjadian penyakit $=\frac{\mathrm{jlh} \text { tnm terinfeksi }}{\mathrm{jlh} \text { tnm yang diamati }} \times 100 \%$

Keterangan:

$\mathrm{jlh}$ tnm terinfeksi $=$ jumlah tanaman terinfeksi

jlh tnm yang diamati $=$ jumlah tanaman yang diamati

d. Perhitungan Keparahan Penyakit

Keparahan penyakit diamati dengan melihat tanaman sampel yang terkena serangan patogen di lapang. Tanaman yang terinfeksi patogen dinilai berdasarkan skor penyakit yang digunakan sesuai dengan kriteria (Tabel 1), kemudian dihitung menggunakan Metode Townsend dan Heuberger:

$$
\mathrm{KP}=\frac{\sum \mathrm{nV}}{\mathrm{zN}} \times 100 \%
$$

Keterangan:

$\mathrm{KP}=$ keparahan penyakit

$\mathrm{n}=$ jumlah tanaman dalam setiap katagori

$\mathrm{v}=$ nilai numerik dari katagori serangan

$\mathrm{z}=$ katagori serangan dengan nilai numerik tertinggi

$\mathrm{N}=$ jumlah seluruh tanaman yang diamati

e. Pengambilan sampel tanah di tanaman yang terduga terserang patogen

Pengambilan tanah dilakukan dengan ring sampel pada kedalaman $0-25 \mathrm{~cm}$ pada daerah sekitar perakaran. Tanaman yang bergejala sakit dibawa ke laboratorium untuk dilakukan pengamatan lebih lanjut.

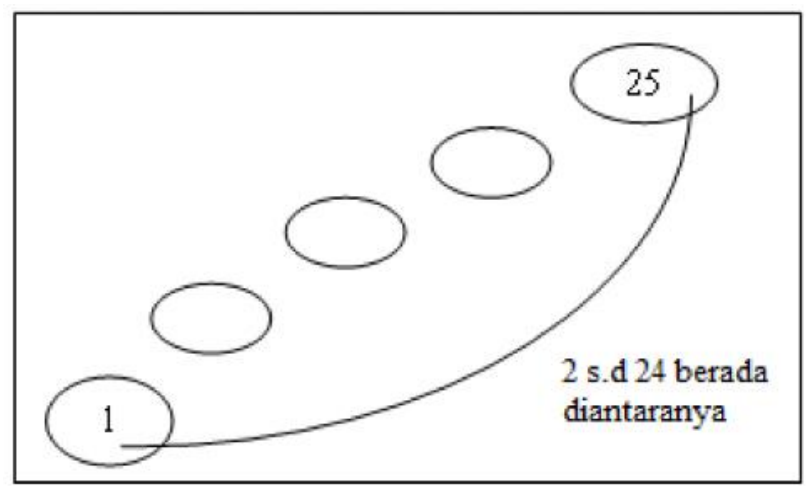

Gambar 1. Sketsa kebun pengamatan 
Tabel 1. Skoring keparahan penyakit nanas

\begin{tabular}{cc}
\hline Keparahan Penyakit $(\%)$ & Nilai Numerik (skor) \\
\hline 0 & 0 \\
$0<x<20$ & 1 \\
$20<x<40$ & 2 \\
$40<x<60$ & 3 \\
$60<x<80$ & 4 \\
$80<x<100$ & 5 \\
\hline
\end{tabular}

\section{f. Isolasi Patogen}

Patogen selalu berasosiasi dengan bagian tanaman yang sakit. Namun demikian isolasi hanya dapat dilakukan untuk patogen yang dapat dikulturkan. Isolasi dapat menggunakan media umum, media semi-selektif.

\section{g. Isolasi dan Identifikasi Jamur}

Jamur patogen dari bagian tanaman yang diduga terserang penyakit oleh jamur diisolasi dengan media PSA (Potato Sukrosa Agar). Identifikasi jamur dilakukan sampai tingkat genus berdasarkan ciri morfologi badan vegetatif dan generatif mengacu pada buku Barnett \& Hunter (1972).

\section{HASIL DAN PEMBAHASAN}

Hasil penelitian pada deteksi patogen menunjukkan bahwa terdapat empat jenis penyakit di areal pertanaman nanas varietas Queen di desa Astomulyo kecamatan Punggur. Penyakit - penyakit tersebut yaitu bercak daun, busuk pangkal batang, busuk buah, dan penyakit layu.

Tanaman yang terserang Curvularia sp. mempunyai gejala bercak kuning pada daun nanas lalu pada tingkat lanjut akan melebar bergabung menjadi bercak yang lebih besar di daun (Gambar 2a). Serangan jamur Curvularia sp. pada tanaman nanas sama dengan gejala serangan Curvularia sp. pada tanaman kelapa sawit. Menurut Susanto dan Prastyo (2013), bercak daun yang disebabkan oleh Curvularia sp. pada kelapa sawit menunjukkan gejala seperti dimulai dengan adanya titik bercak berwarna kecokelatan yang dikelilingi oleh selaput hitam transparan. Hal ini terlihat dari hasil isolasi menunjukkan koloni jamur Curvularia sp. berwarna hitam (Gambar 2b). Isolat jamur Curvularia sp. memperlihatkan konidiofor berwarna coklat, konidia gelap, bersepta 3 sampai 5, biasanya bengkok atau melengkung, dan memiliki satu atau dua sel (Gambar 2c).

Tanaman nanas yang terinfeksi jamur Thielaviopsis sp. mempunyai gejala awal pada daun terlihat bercak terang lalu ujung daun layu, mudah dicabut, dan pembusukan pada pangkal batang (3a). Gejala yang terjadi pada nanas di punggur sama dengan gejala pada nanas di Malaysia yang dinyatakan oleh Hewajulige dan Wijesundera, (2013) yaitu gejala yang ditimbulkan oleh Thielaviopsis sp. pada tanaman nanas antara lain bibit berwarna hitam hangus, daun nanas terdapat bercak daun, busuk hitam, busuk pangkal batang, jaringan yang sakit pada pertanaman nanas akan berwarna gelap seperti ketutup miselium pada permukaan jaringan. Isolasi jamur menunjukkan koloni jamur Thielaviopsis sp. berwarna abu - abu. Hasil isolat jamur Thielaviopsis sp. menunjukkan miselium berwarna putih abu - abu , konodiofor miselium pada lateral pendek, endokonodia hialin batang - berbentuk, cabang lain sel apikal menjadi gelap, tebal berdinding.

Serangan jamur Fusarium sp. pada tanaman nanas mempunyai gejala dimana jamur dapat terlihat di permukaan buah lalu buah busuk di dalam (4a). Serangan jamur ini, pada awalnya hanya berupa titik hitam kecil di salah satu bagian buah nanas kemudian melebar hingga ke dalam buah. Hasil isolasi menunjukkan koloni jamur Fusarium sp. berwarna putih. Hasil isolat jamur Fusarium sp. terlihat warna hifa hialin, konidia terdiri dari 1 sel, dan mikrokonidia seperti bulan sabit dan bersekat, di miselium berwarna putih ke merah muda.

Serangan virus PMWaV ditandai dengan adanya koloni kutu putih yang berada di bawah daun nanas (Gambar 5). Koloni kutu putih ini merupakan vektor virus PMWaV. Hidayat (2006) menyatakan bahwa gejala PMWaV yaitu daun berubah warna menjadi kuning - oranye, mati ujung daun, layu kriting, layu sistemik dan melengkung ke bawah. Berdasarkan penelitian Masdiyawati (2008), bahwa kutu putih di akar memiliki korelasi positif dengan semut dan temprature. Kutu putih akan merusak jaringan yamg berada di daun yang menyebabkan tanaman nanas akan menjadi layu.

Selain isolasi patogen dari bagian tanaman maka hasil penelitian terkait deteksi patogen tanah berhasil diisolasi jamur Penicillium sp., dan Trichoderma sp. (Gambar 5). Jamur Penicillium sp. berpotensi menyebabkan nanas menjadi busuk. Jamur ini merupakan patogen tular tanah, penyakit busuk buah nanas terjadi pada saat masa simpan setelah dipanen. Penyakit ini terjadi karena jamur Penicillium sp. terbawa saat nanas diangkut dari lahan ke tempat penyimpanan. Jamur yang terakhir adalah jamur Trichoderma sp. yang merupakan mikroorganisme tanah yang bersifat saprofit yang secara alami menyerang jamur patogen dan bersifat menguntungkan bagi tanaman. Menurut Gusnawaty et al. (2014), jamur Trichoderma sp. merupakan salah satu jenis jamur yang banyak dijumpai 
pada hampir setiap jenis tanah dan merupakan salah satu jenis jamur yang mampu dimanfaatkan sebagai agens hayati pengendali patogen tanah. Aktivitas jamur ini berada di daerah perakaraan tanaman sebagai mikroparasit sehingga mampu menekan aktivitas patogen tular tanah.

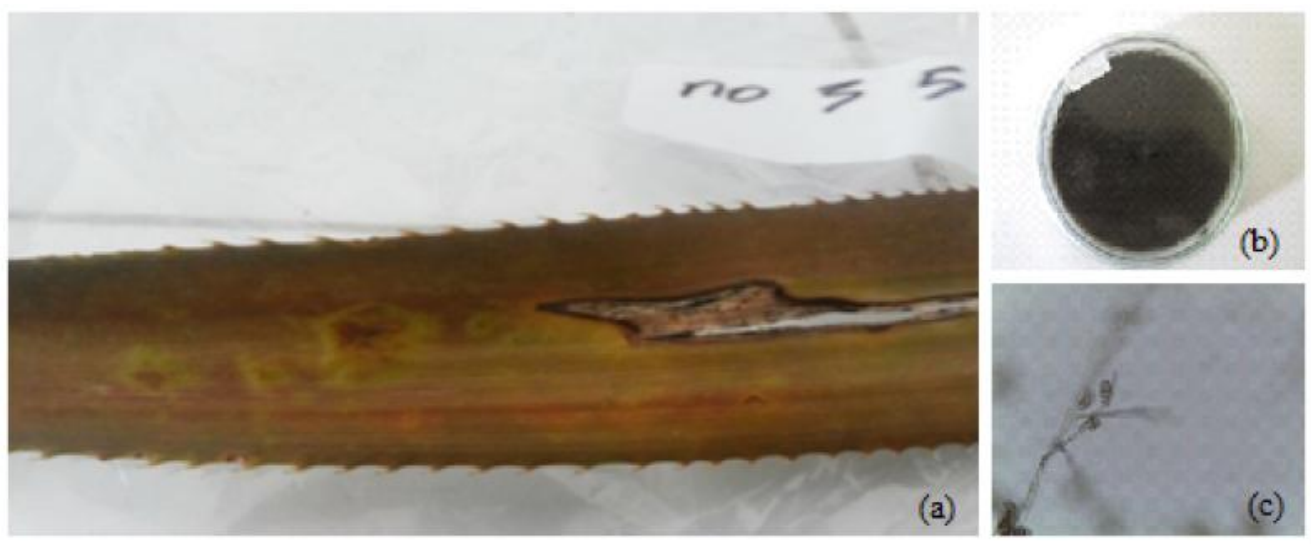

Gambar 2. (a) Penyakit bercak daun yang disebabkan jamur Curvularia sp. (b) Isolat jamur Curvularia sp. secara makroskopis, (c) Isolat jamur Curvularia sp. secara mikroskopis
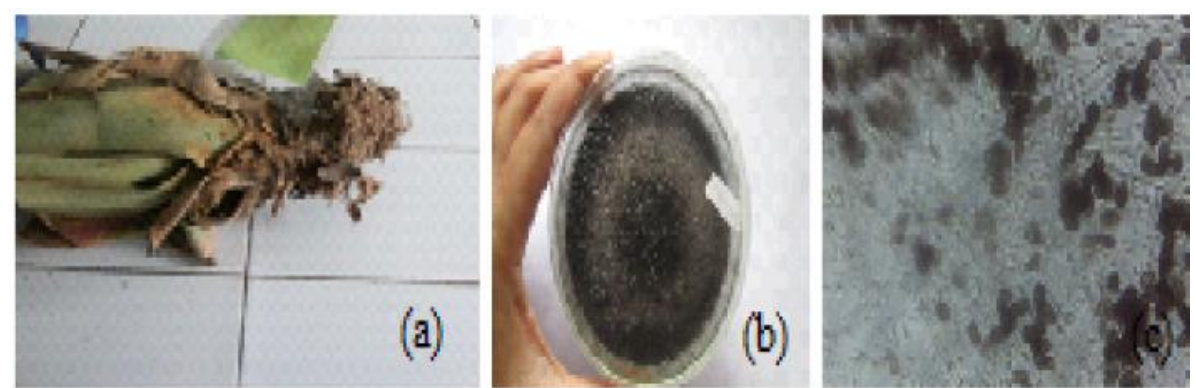

Gambar 3. (a) Penyakit busuk pangkal batang tanaman yang disebabkan jamur Thielaviopsis sp. (b) Isolat jamur Thielaviopsis sp. secara makroskopis (c) Isolat jamur Thielaviopsis sp. secara mikroskopis
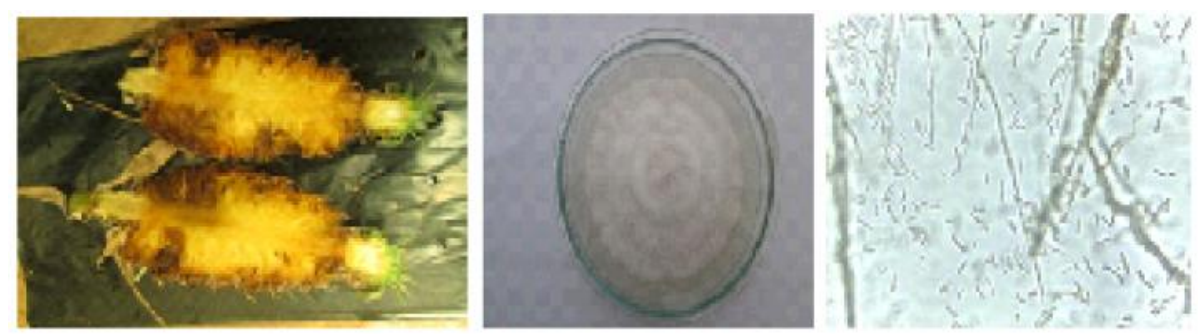

Gambar 4. (a) Penyakit busuk buah tanaman yang disebabkan jamur Fusarium sp., (b) Isolat jamur Fusarium sp. secara makroskopis (c) Isolat jamur Fusarium sp. secara mikroskopis
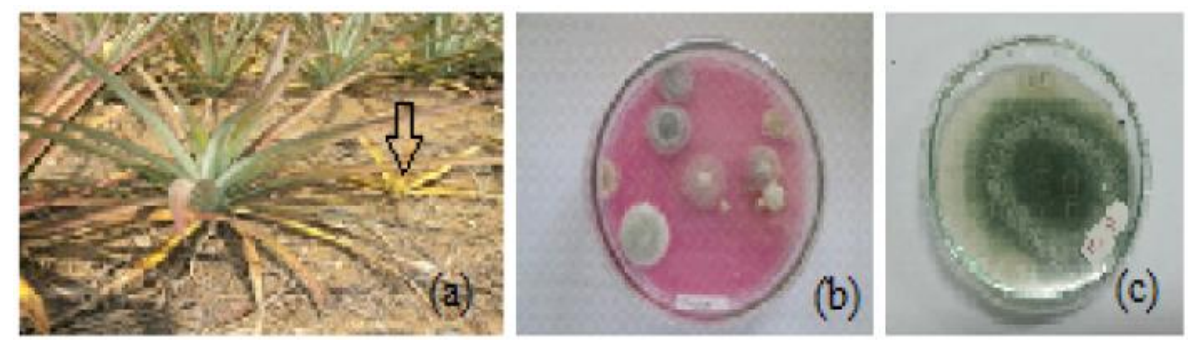

Gambar 5. (a) Penyakit layu tanaman yang disebabkan Virus PMWaV, (b) Isolat Penicillium sp. pada media rose bengal, Isolat Trichoderma sp. pada media PSA 
Tabel 2. Keterjadian dan Keparahan Penyakit

\begin{tabular}{|c|c|c|c|c|c|c|c|}
\hline \multirow{3}{*}{ Patogen } & \multirow{3}{*}{ Penyakit } & \multicolumn{6}{|c|}{ Umur tanaman } \\
\hline & & \multicolumn{2}{|c|}{ Muda (5-7 bulan) } & \multicolumn{2}{|c|}{ Sedang (8-11 bulan) } & \multicolumn{2}{|c|}{ Tua (12 bulan) } \\
\hline & & KP 1 & KP 2 & KP 1 & KP 2 & KP 1 & KP 2 \\
\hline PMWaV & Penyakit layu & $52 \%$ & & - & & $16 \%$ & \\
\hline Curvularia sp. & Bercak daun & $17,70 \%$ & $8,40 \%$ & $24 \%$ & $8,80 \%$ & $21,30 \%$ & $7,60 \%$ \\
\hline Thielaviopsis sp. & $\begin{array}{l}\text { Busuk pangkal } \\
\text { batang }\end{array}$ & $16 \%$ & $7,20 \%$ & $28 \%$ & $15 \%$ & $25,30 \%$ & $9,30 \%$ \\
\hline Fusarium sp. & Busuk buah & - & - & $8 \%$ & $5 \%$ & $14,60 \%$ & $9 \%$ \\
\hline
\end{tabular}

Keterangan: KP 1 = Keterjadian Penyakit, KP 2 = Keparahan Penyakit

Berdasarkan pengamatan kejadian penyakit di areal pertanaman nanas, terlihat bahwa serangan patogen virus PMWaV banyak terjadi di lahan. Serangan PMWaV banyak menyerang tanaman berumur 5-7 bst dengan tingkat keterjadian penyakit sebesar $52 \%$ (Tabel 2). Hal ini terjadi karena saat tanaman nanas masih muda, tanaman ini ditutup dengan mulsa. Mulsa menyebabkan area di bawah tanaman nanas menjadi lembab sehingga membuat kutu putih tertarik untuk berkembang biak. Tidak ada serangan virus PMWaV pada saat tanaman nanas berumur sedang, tetapi virus PMWaV menyerang kembali saat nanas berumur tua sebesar 16\%. Nanas varietas Queen memiliki ketahaan lebih baik terhadap serangan PMWaV. Nanas varietas ini mampu membuat kembali daun yang terkena serangan menjadi hijau kembali setelah beberapa minggu daun mengalami gejala serangan (Hidayat, 2006).

Jamur Curvularia sp. menyerang tanaman nanas pada berbagai umur. Pada umur tanaman 5-7 bst tingkat keterjadian penyakit sebesar $17,7 \%$ dan keparahan penyakit $8,4 \%$, pada umur tanaman $8-11$ bst tingkat keterjadian penyakit sebesar $24 \%$ dan keparahan penyakit sebesar $8,8 \%$, sedangkan pada umur tanaman 12 bst keterjadian penyakit mencapai $21,3 \%$ dan keparahan penyakit mencapai $7,6 \%$. Keterjadian dan keparahan penyakit tertinggi terjadi pada umur tanaman sedang. Hal ini dikarenakan gejala serangan jamur Curvularia sp. mulai terlihat jelas pada umur sedang. Jamur ini sebenarnya menyerang pada stadium pembibitan. Hal ini didukung oleh penelitian Solehudin (2012) dalam Susanto dan Prastyo (2013), menyatakan jamur Curvularia sp. menyerang di pembibitan sebesar $38 \%$.

Keterjadian dan keparahan penyakit busuk pangkal batang yang disebabkan oleh jamur Thielaviopsis sp. paling tinggi mencapai $28 \%$ dan $15 \%$ terjadi pada saat tanaman berumur 8-11 bst. Jamur
Thielaviopsis sp. menginfeksi tanaman nanas melalui luka mekanis tanaman yang disebabkan oleh penyiangan gulma yang tidak hati-hati. Penyiangan gulma dilakukan pada saat umur tanaman $5-7$ bst. Jamur ini sebenarnya menyerang tanaman berumur muda, namun gejala serangannya akan terlihat jelas pada umur tanaman sedang.

Jamur Fusarium sp. banyak menyerang tanaman pada saat berumur 12 bst dengan tingkat keterjadian penyakit sebesar 14,6\% dan keparahan penyakit sebesar 9\%. Jamur ini mudah menginfeksi tanaman ketika lingkungan lembab. Hasil uji patogenisitas isolat patogen menunjukkan bahwa isolat tersebut dapat menginfeksi tanaman nanas sehat.

\section{KESIMPULAN}

Patogen yang terdapat di areal pertanaman nanas varietas Queen di Desa Astomulyo, Kecamatan Punggur, Lampung Tengah yaitu PMVaV, jamur Curvularia sp., Thielaviopsis sp., Fusarium sp., Penicillium sp. Keparahan penyakit tertinggi pada tanaman nanas berumur 5-7 bst disebabkan oleh jamur Curvularia sp. dengan persentase sebesar $8,4 \%$, keparahan tertinggi tanaman nanas berumur $8-11$ bst disebabkan oleh jamur Thielaviopsis sp. sebesar 15\%, dan keparahan tertinggi tanaman nanas berumur 12 bst disebabkan oleh jamur Thielaviopsis sp. sebesar 9,3\%.

\section{DAFTAR PUSTAKA}

Barnett, H.I. dan B.B. Hunter. 1972. Illustrated Generan Of Imperfect Fungi. Third Edition Bur Geus Publishing Company New York. 218 pp

Gusnawaty, H.S., M. Taufik., L. Triana., dan Asniah. 2014. Karakterisasi morfologis Trichoderma 
spp. indigenos Sulawesi Utara J. Agroteknos. 4(2): 87 - 93.

Hidayat, D. 2006. Respon Lima Varietas Nanas Terhadap Infeksi Pineapple Mealbug Wilt Associated Virus Melalui Vektor Dysmicoccus Brevipes (Cockerell) (Hemiptera: Pseudococcidae). Skripsi. Fakultas Pertanian Institut Pertanian Bogor. $46 \mathrm{hlm}$.

Hewajulige, I.G.N. dan R.L.C. Wijesundera. 2014. Thielaviopsis paradoxa, Thielaviopsis basicola (Black Rot, Black Root Rot). In: postharvestdecay control strategies. S.B. Banos (Ed.). Academic Press - Elsivier inc. London, hlm: $287-308$.

Lisnawita, Supramana, dan G.. Suastika. 2011. Kontribusi Pratylenchus brachyurus dalam menginduksi gejala layu pada tanaman nanas (Ananas comosus (L.) Merr). J. Agroteknos. 1 (2): 65-70.
Masdiyawati. 2008. Hubungan antara kepadatan kutu putih di akar dengan kepadatan kutu putih dan semut di tajuk tanaman (Ananas comosus L.). Skripsi. Fakultas Pertanian Institut Pertanian Bogor. $25 \mathrm{hlm}$.

Pusat Data dan Sistem Informasi Pertanian (PUSDATIN). 2015. Ekspor Impor Komoditas Pertanian. Buletin Triwulanan. 7(1) : 1-13.

Sether, D.M. and J.S. Hu. 2002. Yield impact and spread of pineapple mealybug wilt-associated virus-2 and mealybug wilt of pineapple in Hawaii. Plant Diseases. 86: 867-874.

Susanto, A., dan A.E. Prastyo. 2013. Respons Curvularia lunata penyebab penyakit bercak daun kelapa sawit terhadap berbagai fungisida. J. Fitopalogi Indonesia. 9(6): 165172. 